\title{
紡績工場における掃除法の合理化に関する研究*
}

（第 12 報）ブロークリーナの特性执よび効果

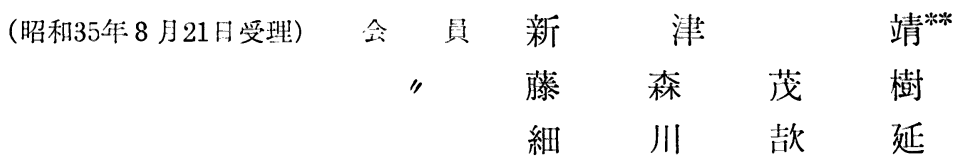

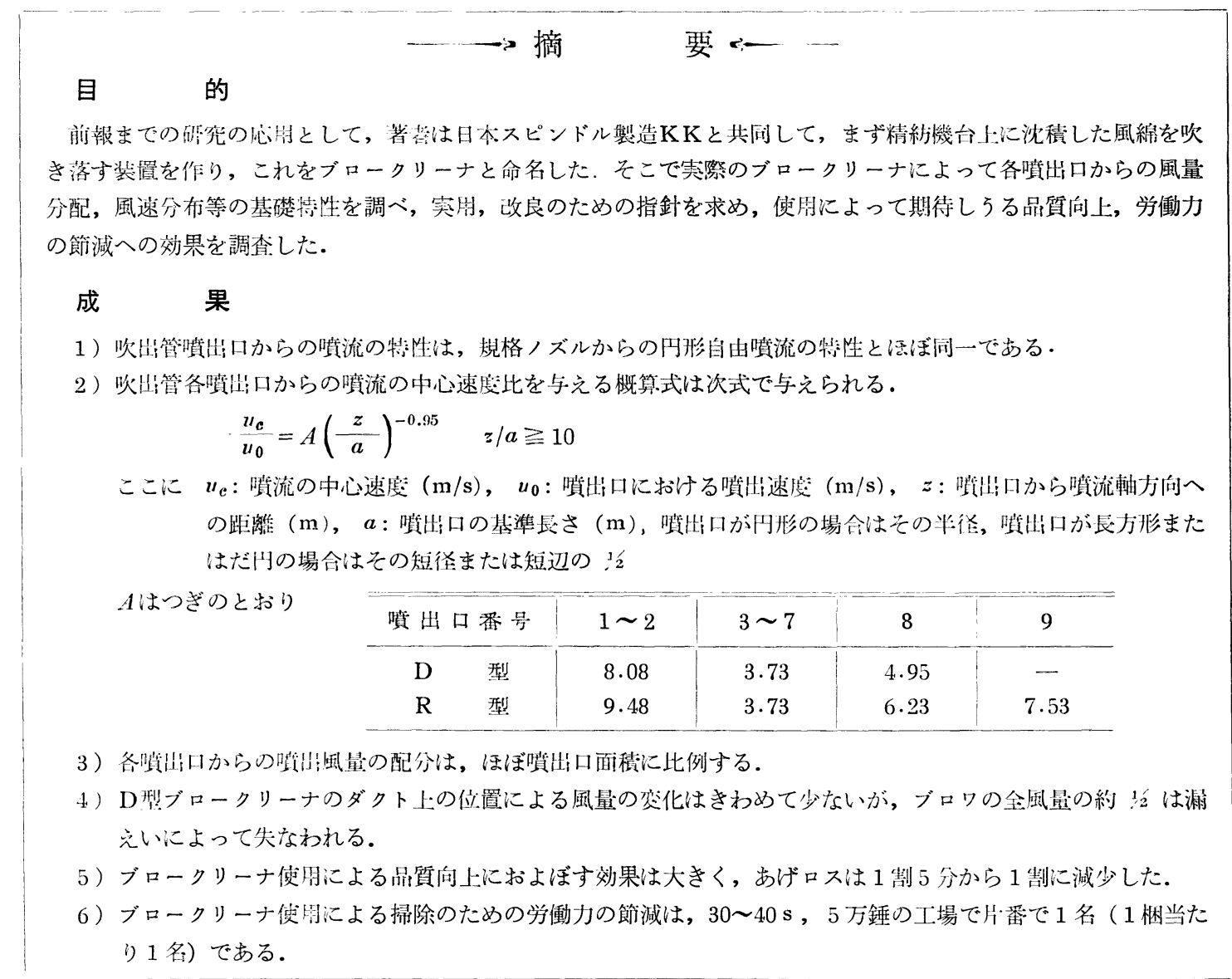

\section{2. ブロークリーナの特性}

薯哮はこれまで11報にわたって，紡績工場における㛿 除法の会理化のために，空父力を必时して線じんの吹き そばし，吸い耿りを行ならべきこと，その際に吹き出し ノズルや吸い込みノズルの掃除特性はどのようなるので あるかまた諮計のための一般式などを研究して来た。

しかして紡績工程では, 開俵から商品化の最終段階ま
で，すべて風線やじんあいの掃除を必要とするが，特沉 精紡工程が機台数の多いこと, 登生風線が多く, これが 乎切れ, 品質に影響すること, 従来掃除人工を多く必要 としたことなどのために，機柀的掃除法の採朋が要求さ れ,すでに一部ではトラベリング ファンが採朋されてい る.しかし出力の大きいファンでただ強力に機台を吹く だけでは，風線の吹き落しにはならず，かえってこれを 飛散させて紡系汇飛びつきを起させるなど，好ましい結

* Studies on Rationalization of Cleaning Method in Spinning Mills. Part 12: Characteristics and Efficiency of Blo-Cleaner. (第 1 報 11 卷 1 号, 第 2 報 11 卷 5 号, 第 3 報 11 卷 6 年, 第 4 報 11 卷 10 岇, 第 5 報 12 巻 1 号, 第 6 報 12 卷 5 号, 第 7 報 12 巻 10 号, 第 8 報 13 巻 5 号, 第 9 報 13 卷 7 号, 第10報 13 巻 8 号, 第11報 13 卷 12 号飞所載)

** Y. Niitsu, Member. 大阪大学, S. Fujimori, Member. Y. Hosokawa, 姬路工業大学 
果は得られない、すなわら最少の陲力で最も㛿除を必恶 とする個所を重点的に吹き，風編を機台から床面に吹さ 落すことが望ましい。

そこで著者は日有スピンドルと共同で，2つの掃除装 置を完成し，集団的にこれを採用している工場において 実際の作動特性と接除效果を調べた。

すなわち現在同社で製造している装置はD型ブローク リーナと $\mathrm{R}$ 型ブロークリーナであるが，木ず $\mathrm{D}$ 型ブロー クリーナは算 203 図の写真に示すよ

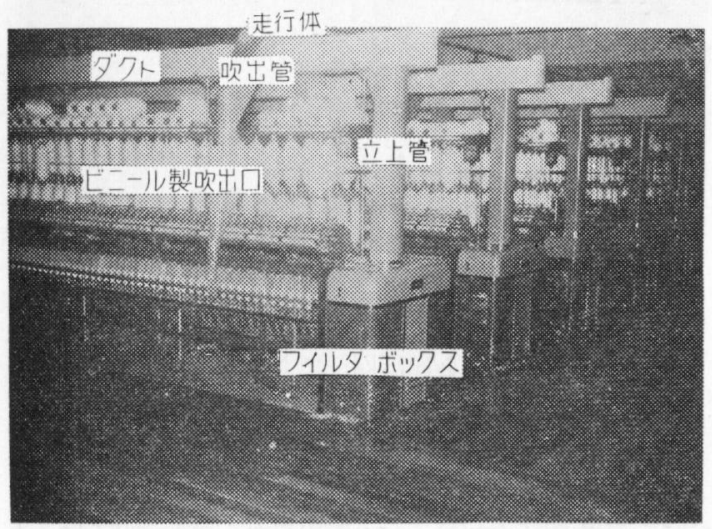

（第 203 困）

ズの排父をダクトで精紡機の上部に導き，このダクト上 を走る送行俗から精紡機両側にたれ下っている吹出管に 空気を゙送り，吹出管にあけられた各筫出口から精紡機台 の特に掃除を必要とする個所に向けて噴出するようにし てある、ニューマニーズの排気量は, $8.8 \mathrm{~m}^{3} / \mathrm{min}$ に道 し, 従来これを集線器の下から床面に放出しているが， この文流が床面上の風編を゙舞い上らせる欠点がある。そ こでこの排気を精紋機台上のダクトに導き，機台の吹き 払い掃狳に用いようとする案は,すでに新津、提唱した ものであり，この際国定されたダクトの任意の場所から

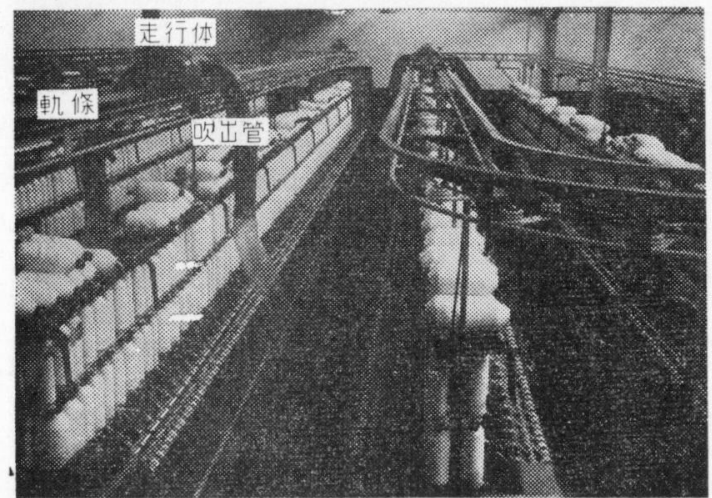

(第 204、困)

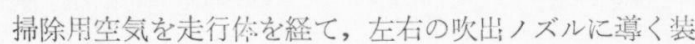
置も新津の考案である。

つぎにR型ブロークリーナは筷 204 図に示すように, 精紡機上に談けたレールの上をモートルブロワを有す る走行位が自己駆動して，これから精紡機両側に送風す るものである、したがってR型は他の機器から独立して おり，各位置における風量将常に一定しているが，D型

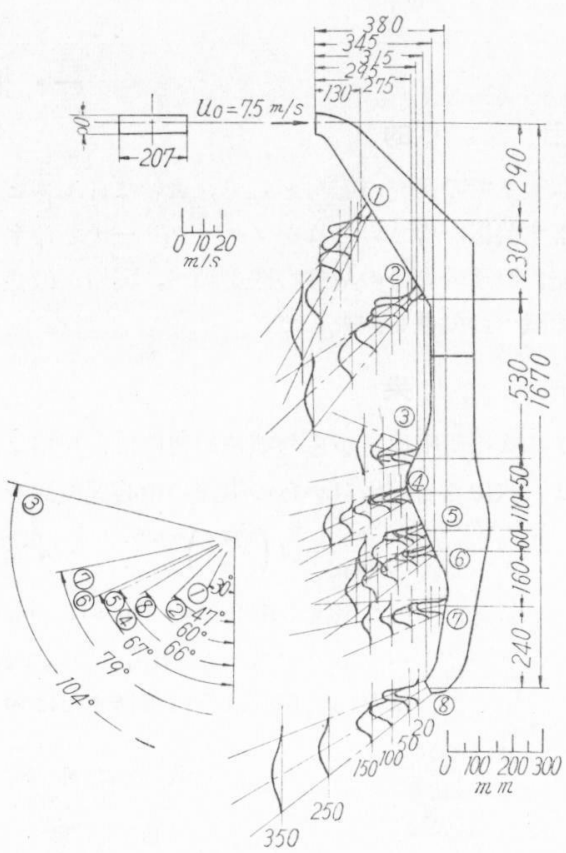

（第 205 図）

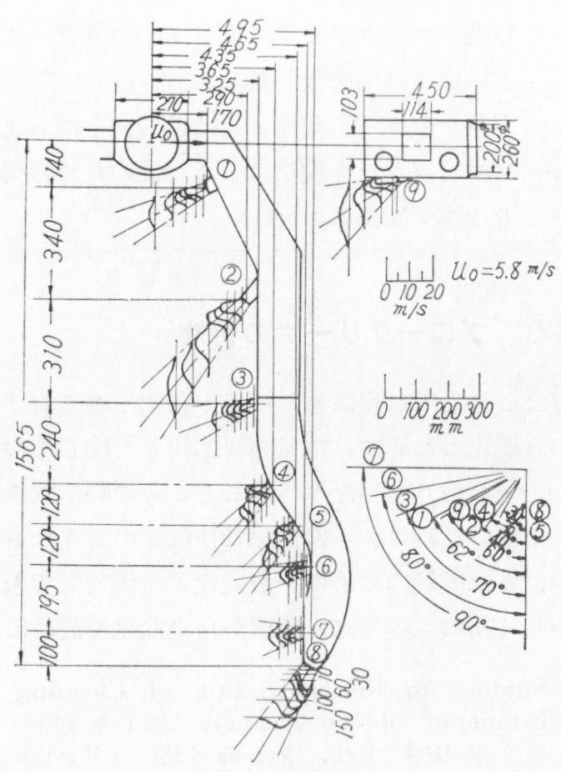

(第 206 図) 
はダクト内の摩擦損失, 漏えい括よびニニーマニーズの フィルタボックス内の風綿の堆積量の多少によって, 走行時の状態, 位置により風量が変化する.

第 205 図はD型ブロークリーナの，䈐 206 図は R 型ブ ロークリーナの各噴出口からの噴流の中央断面内の風速 分有を図示したもので， D型の風量は $4.65 \mathrm{~m}^{3} / \mathrm{min}, \mathrm{R}$ 型は $4.11 \mathrm{~m}^{3} / \mathrm{min}$ である.これらの風速分布の測定に は外径 $1 \mathrm{~mm}$, 内径 $0.8 \mathrm{~mm}$ の检定ずみピトー管とゲ ッチンゲン型圧力計を用い，送風機の全送風量は $125 \phi$ の規格入口ノズルによった.

$\mathrm{D}$ 型， R 型の各噴出口の掃除対象個所は第 1 表のと抒 りである。

各噴出口の大きさは第 2 表のとおりである。

$\mathrm{D}$ 型， $\mathrm{R}$ 型とも各噴出口からの噴流の速度分布は先に のペた規格ノズルの円形噴出口からの風速分布と同椂に Gauss の誤差関数としてあらわされる状態であり，その 特性もまた同じ傾向のものとなる。

（第 1 表）

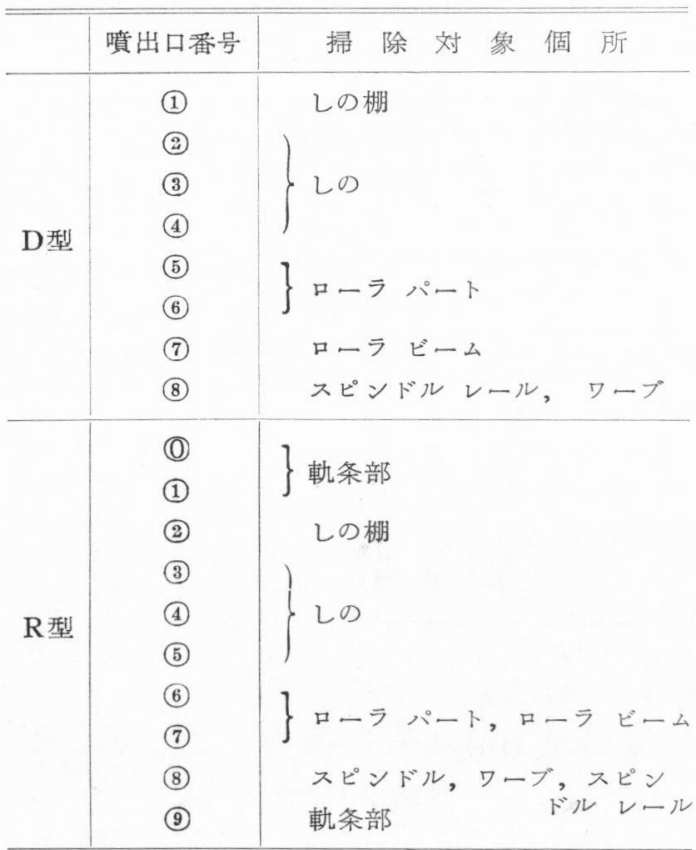

第 207 困はD型， R 型の吹出管各噴出口からの哮流の 㖶写真であって，筹 205，206，207図からわかるよ5に

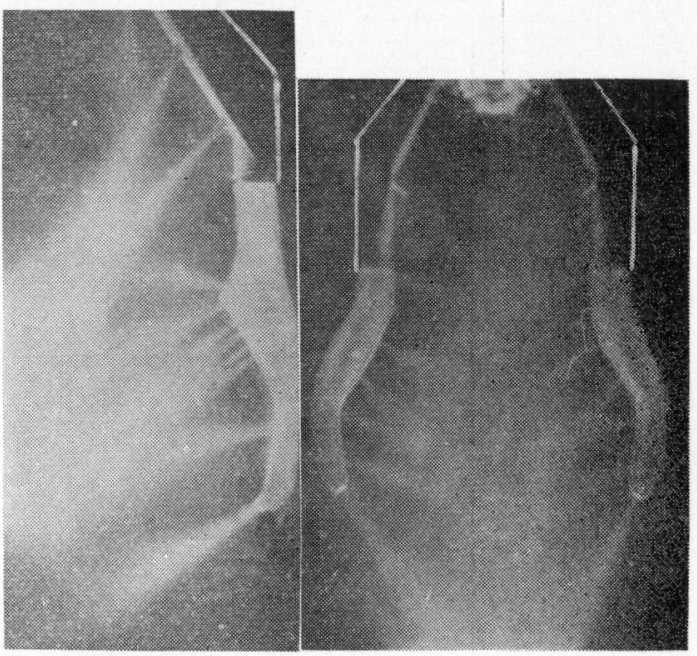

$\mathrm{R}$ 型

(第 207 図)

$\mathrm{D}$ 型
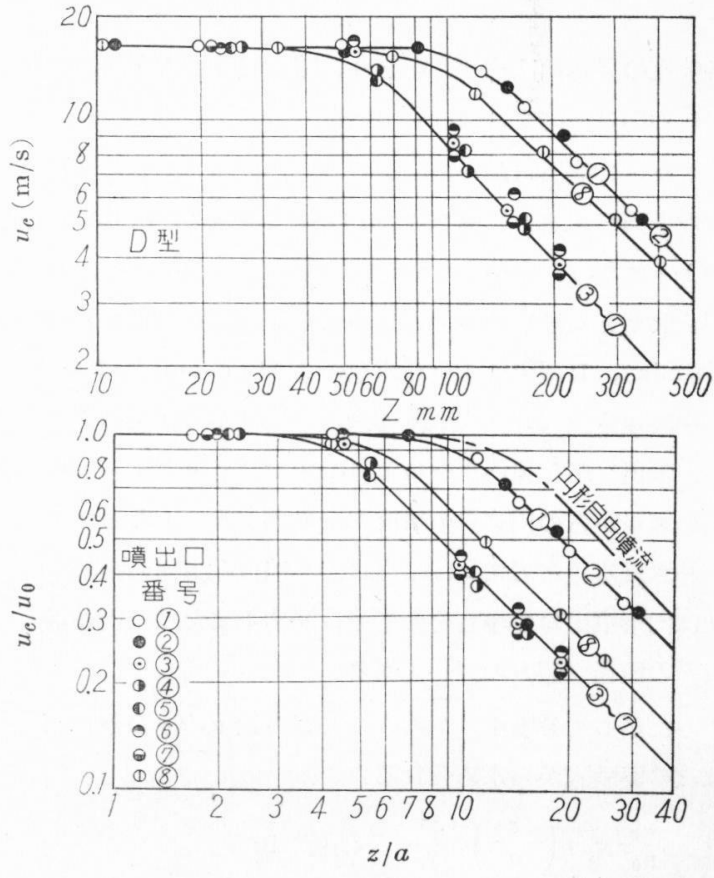

(第 208 図)

（第 2 表）

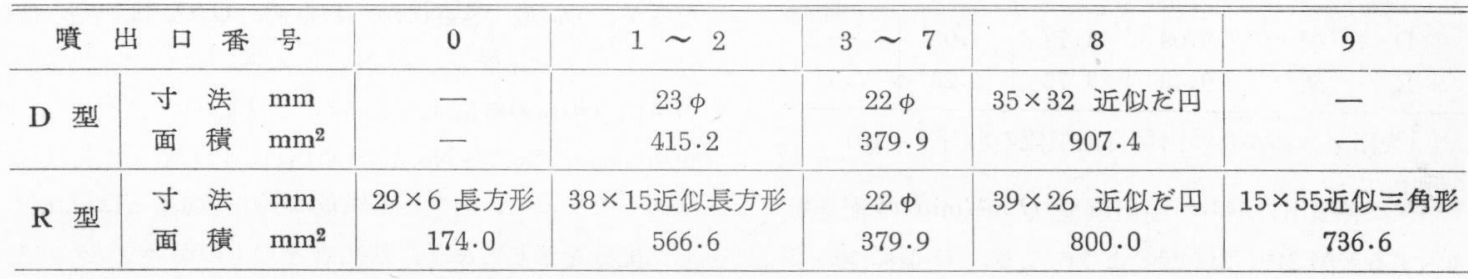



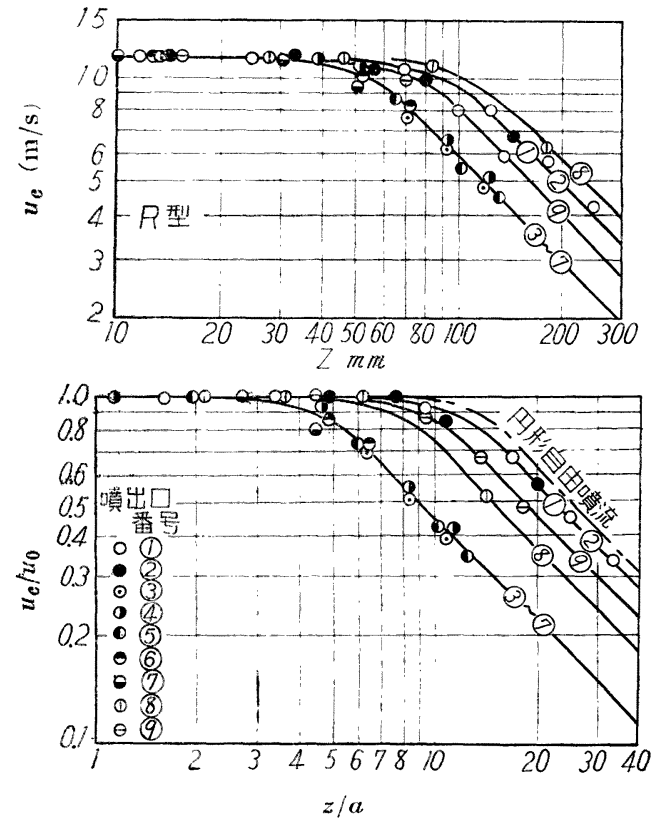

(第，209 㚭）

各噴流の展開角は約 $20^{\circ}$ をとり, 噴出父流のうj间は各噴 出口の開口方向または取付力问に一致している.

これら各噴出口からの噴流の中心速度 $u_{e} \mathrm{~m} / \mathrm{s}$ の減铥 状沉を図示すると, 第 208 図 ( D 型), 第 209 図 (R型) のようになり, 各噴出口に括ける噴出速度 $u_{0} \mathrm{~m} / \mathrm{s}$ はD 型; R型とも湮ぼ一定で，D型では $16.5 \mathrm{~m} / \mathrm{s}\left(Q_{0}=4.65\right.$ $\left.\mathrm{m}^{3} / \mathrm{min}\right), R$ 型では $12 \mathrm{~m} / \mathrm{s}\left(Q_{0}=4.11 \mathrm{~m}^{3} / \mathrm{min}\right)$ である.

中心速度比 $u_{c} / u_{0}$ の減衰状態は筑 $208 ， 209$ 図の上5 に，質出口から遠い点 $z / a \geqq 10$ では，各分布線とも䙺 格ノズルからの网形自由噴流の分布線と平行となってあ らわされる。ここで $z$ は噴出口から噴流軸方向の距離: $a$ は円形豍出口の場合その半径, 長方形をたはだ円の場 合その短经（暹）の詒である。

したがって谷賴出口からの中心湠度比 $u_{e} / u_{0}$ の概算倬 は次の実験式から求められる.

$$
\frac{u_{c}}{u_{0}}=A\left(\begin{array}{c}
z \\
a
\end{array}\right)^{-0.95} \quad z / a \equiv 10
$$

ここで $A$ の值は次の表のとおりである.

\begin{tabular}{c|c|c|c|c|c} 
噴出口番号 & $1 \sim 2$ & $3 \sim 7$ & 8 & 9 \\
\hline $\mathrm{D}$ & 型 & 8.08 & 3.73 & 4.95 & - \\
$\mathrm{R}$ & 型 & 9.48 & 3.73 & 6.23 & 7.53 \\
\hline
\end{tabular}

（規格ノズルからの円形自由噴流の場合 $A=10$ )

つぎに各賲出口からの噴出風量 $Q \mathrm{~m}^{3} / \mathrm{min}$ の配分を 図示すると第 210，211 図のようになる，D 型について
噴出口面積 $A\left(\mathrm{~cm}^{2}\right)$

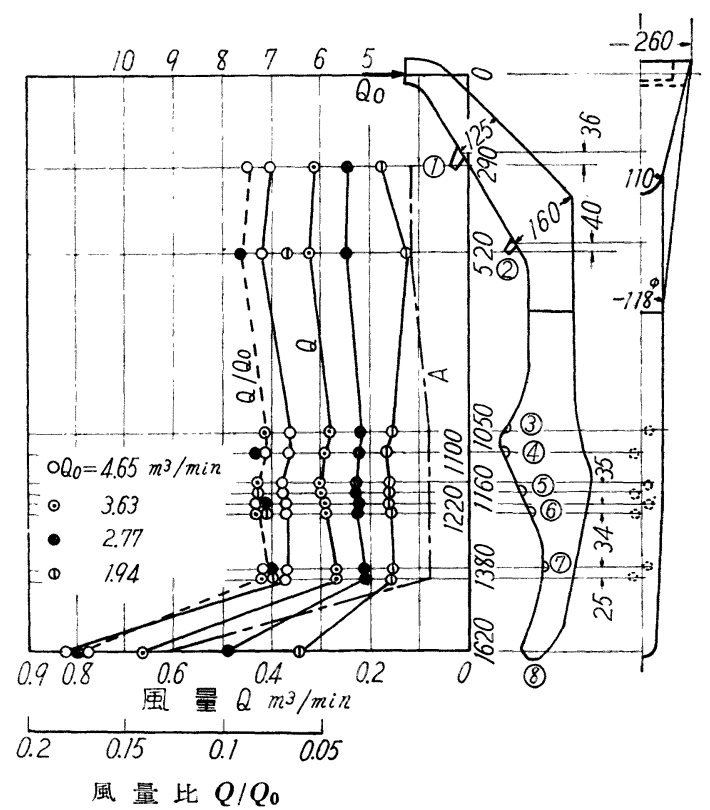

(第 210 欧)

噴出口面穔 $A\left(\mathrm{~cm}^{2}\right)$

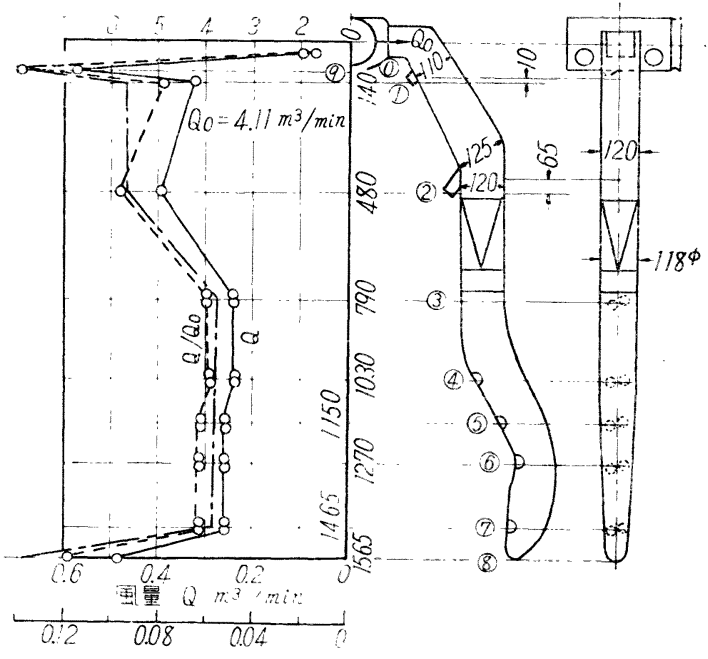

風量比 $Q / Q_{0}$

$$
\text { (第 } 211 \text { 汹) }
$$

は,ブロワからの全送風量 $Q_{0} \mathrm{~m}^{3} / \mathrm{min}$ が间述のように 送行伶位置フフィルタボックスの状態等によってこと なるが， $Q_{0}$ の大きさにかかわらず， $Q / Q_{0}$ は一定の配 分となり，吹壮管先端の No. 8 の貲结口を除いて，他 の賃南山からの風量はにぼ同じでありまたR型では， 吹怡管部の No. 3〜No. 7 の賃出口からの暊出風量はほ ぼ间じであって, 唡型とも風量は噴出口面積とほぼ比例 した配分を亦して打り，吹出管そのものがエアタンク 


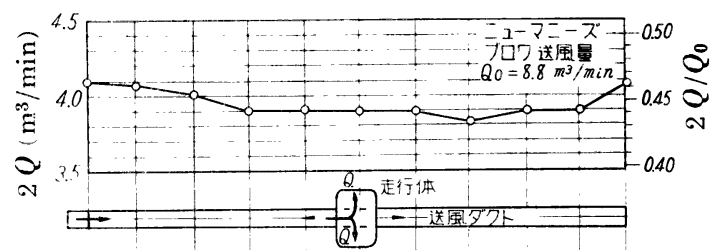

$-397-1536-1397-1536-1397-1536-1397-1536+1397+1257$

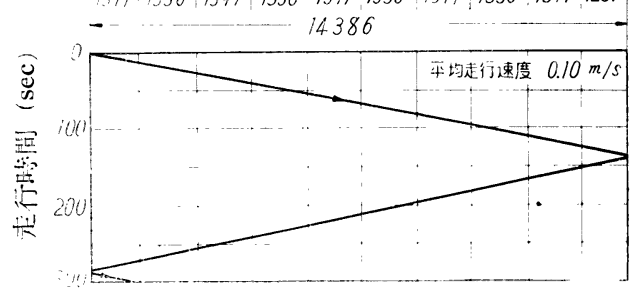

(急 212 以)

の役制を果していると考えられるから，櫴出口面積を適 些にえらべば，所要の風量分配をらることができる。

前にのべたようにD型は走行時の位膡によって風量が 突化すると考えられるが，その状況を図示すると第 212 図の上図のようになり,ダクト両端で最大風量となり， ダクト末端から約 $1 / 3$ の点で最小となる. 図は $Q_{0}=8.8$ $\mathrm{m}^{3} / \mathrm{min}$ でニューマニーズ フイルタボックス内に風綿 が少なく，したがって $Q_{0}$ の大きな場合であるが，ボッ クス内の風綿が多くなって $Q_{0}$ が少なくなってもその風 最比 $Q / Q_{0}$ はあまり変化がない，図によるとブロワ全送 風量の約半分は，漏えいによって失なわれていることを 知る.

なお走行体の走行速度は $\mathrm{D}$ 型では $0.10 \mathrm{~m} / \mathrm{s}, \mathrm{R}$ 型で は $0.15 \mathrm{~m} / \mathrm{s}$ であって, D型では精絲機 1 台（有効長さ $14386 \mathrm{~mm}$ ) に対してブロークリーナ 1 台となるから， 第 212 図の下図のよ5に, 同一点を通る周期は位置に よって異なるが中央部で約 $140 \mathrm{sec}$ となり， R 型で第 204 図のよ5亿精紡㙨 2 台を巡回する場合（レール 全長 $32445 \mathrm{~mm}$ ) では, 周期は約 $210 \mathrm{sec}$ である.なお $\mathrm{D}$ 型 は间述のとおり送風はニューマニーズの排気利用で, 走 行体の歌動はチンローラ軸よりアプライドシャフト駆 動の型式と単独モータ（ $1 / 8 \mathrm{P} ）$ による型式とがある。 た $\mathrm{R}$ 型は出力 $125 \mathrm{~W}$ のモータによって走行および送風 の岀作朋を行なっている.

\section{3. ブロークリーナの効果}

ブロークリーナの使用による効果として

(1) 品質の向上

(2) 掃除のための人員の節減

つ 2 䐜目が考兄られる.

まず品質の向上については,ブロークリーナの使用に
よって,ドラフト中に飛散付着しよ5とする短緋維が吹 きとばされるため，系汇節がなくなり品質が问上し，あ げロスは 1 制 5 分から 1 制汇娍少してくる.

つぎに掃除に装する労働力の節隇の点については，は っきりした数傎はその性質上確認しにくいが，玉揚工， 台持厂，巻とりエの5けもつ掃除の仕索量が減少し，と くにしのかたの掃除はブロークリーナの伐朋によって, 绿とんど行なわず付すむようになったので，30〜 $40 \mathrm{~s}$ ，

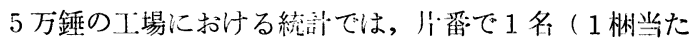
りの人員で約 1 名〉の学衝力の節隇となる.

なお，さらに舆棚，ローラパートの脷除を対象とし て改良を加え，吹きとばされた渢綰塊の除去として吸取 ノズルの併湖を卷党れば, 労衝力の節隇はさらに大きく なるものと路えら礼る。

44. 結語

ブロークリーナの基礎特性を実験的に調べ，その効果 を調査して，つぎにあげるような結果をえた。

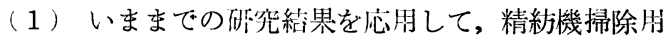
ブロークリーナを等俳し，集団運転の笑績を調べた。

（2）吹出管各噴出口からの噴流の特性は，規格ノズ ルからの円形自由櫴流の特性とほぼ同一である.

（3）吹出管各噴出口からの唺流の中心速度比を与兄 る概算.式は次式で与えられる。

$$
\frac{u_{e}}{u_{0}}=A\left(-\frac{z}{a}\right)^{-0.55}, \quad z \geq 10 a
$$

$A$ の值は次のとおりである.

\begin{tabular}{ccccc|c}
\hline \multicolumn{2}{c}{ 噴 $\begin{array}{c}\text { 口 } \\
\text { 番号 }\end{array}$} & $1 \sim 2$ & $3 \sim 7$ & 8 & 9 \\
\hline $\mathrm{D}$ & 型 & 8.08 & 3.73 & 4.95 & - \\
$\mathrm{R}$ & 型 & 9.48 & 3.73 & 6.23 & 7.53
\end{tabular}

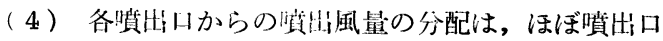
面糟に比例する。

（５） D裂ブロークリーナのダクト上の位置による風 量の䍐化はきか女て少ないが,ブロワの全風量の約商は 浅えいによって坐なわれる。

（6）ブロークリーナ使脚よる品質向上に抢よぼす 效果は大きく, あげロスは 1 虽 5 分から 1 割に減少して いる.

（7）ブロークリーナ使䐪による搞除のための学働力 の䬣減は，30〜 $40 \mathrm{~s} ， 5$ 万錘の工場で片番で 1 名（1梱 当たり 1 名）となる.

第 1 報緒言でのべたように,紡績工場の掃除法の改良， 
合理化は大きな問題であり，著者はこれは空気力の心淍 によって改善されるだろうと考えて, その基礎的研究と 灾用について述べてきた。

ブロークリーナは精紡機のみならず, カード, 練条, 巻糸機などにも応用しうるものであり,この方面にのび て行くものと信ずる.これらの研究は今後引き続いて行 なら予定であり，一応ここでかく筆するが，この研究は 日本スピンドル製造の御援助によるものであり，現場実 験は日東紡續泊工場の御好意による.ここに関係省各位
に対し厚く謝意を表します。

\section{参考文献}

1) 新津, 倉橋; ニューマニーズの設計とその性能研 究 (第 10 報)， ニューマニーズの排気を利用する ブロークリーナの実験, 本誌, 5, 10 (1952-10)

2) 新津, 藤森, 細川; 紡績工場比和ける掃除法の合 理化阔祭す研究 (第 7 報), 本誌, 12,10 (1959-10) 